\title{
Caminibacter hydrogeniphilus gen. nov., sp. nov., a novel thermophilic, hydrogen-oxidizing bacterium isolated from an East Pacific Rise hydrothermal vent
}

\author{
1,2,3 Laboratoire de \\ Microbiologie et de \\ Biotechnologie des \\ Extrêmophiles, \\ Département de \\ Valorisation des \\ Produits ${ }^{1}$, Laboratoire \\ Environnement Profond, \\ Direction des Ressources \\ Océaniques $^{2}$ and \\ Laboratoire \\ "Biotechnologie et \\ Molécules Marines", \\ Département de \\ Valorization des \\ Produits $^{3}$, IFREMER \\ Centre de Brest, BP 70, \\ 29280 Plouzané, France
}

\author{
Karine Alain, ${ }^{1}$ Joël Querellou, ${ }^{1}$ Françoise Lesongeur, ${ }^{1}$ Patricia Pignet, ${ }^{1}$ \\ Philippe Crassous, ${ }^{2}$ Gérard Raguénès, ${ }^{3}$ Valérie Cueff ${ }^{1}$ \\ and Marie-Anne Cambon-Bonavita ${ }^{1}$
}

Author for correspondence: Karine Alain. Tel: +332982245 53. Fax: +33298224757. e-mail: Karine.Alain@ifremer.fr

\begin{abstract}
A novel thermophilic, anaerobic, hydrogen-oxidizing bacterium, designated strain AM1116', was isolated from an East Pacific Rise hydrothermal vent sample. The cells were rod-shaped (1.0-1.5 $\times 0.5 \mu \mathrm{m})$, motile with polar flagella. They grew at temperatures between 50 and $70^{\circ} \mathrm{C}$ (optimum $60^{\circ} \mathrm{C}$; doubling time approximately $1.5 \mathrm{~h}$ ), at between $\mathrm{pH} 5.0$ and 7.5 (optimum around pH 5.5-6.0) and in between 10 and $40 \mathrm{~g} \mathrm{NaCl} \mathrm{I}^{-1}$ (optimum 20-25 $\mathrm{g} \mathrm{I}^{-1}$ ). Cells grew chemolithoautotrophically in a $\mathrm{H}_{2} / \mathrm{CO}_{2}$ atmosphere $(80: 20 ; 200 \mathrm{kPa})$. Poor heterotrophic growth was observed on complex organic substrates. Elemental sulphur and nitrate served as electron acceptors, respectively yielding hydrogen sulphide and ammonia (doubling times were equal with the two electron acceptors). In contrast, when cystine was used as electron acceptor, growth was poor. The $G+C$ content of the genomic DNA was $29 \pm 1 \mathrm{~mol} \%$. Phylogenetic analyses of the 16S rRNA gene located the strain within the $\varepsilon$-Proteobacteria, in the bacterial domain. On the basis of 165 rDNA sequence comparisons, physiological and biochemical characteristics, it is proposed that the isolate should be described as the type species of a new genus, Caminibacter gen. nov., as Caminibacter hydrogeniphilus sp. nov. The type

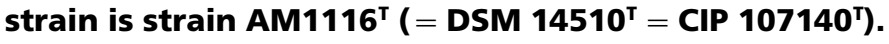
Keywords: deep-sea hydrothermal vent, thermophile, lithotroph, $\varepsilon$-Proteobacteria,
Caminibacter hydrogeniphilus

\section{INTRODUCTION}

The subclass $\varepsilon$-Proteobacteria comprises a complex group of Gram-negative, microaerophilic and/or anaerobic, chemoorganoheterotrophic or chemolithotrophic bacteria that are found in a variety of habitats. Many members of this group are eukaryotic pathogens. It currently contains two major lineages. The first lineage encompasses the genera Arcobacter, Sulfurospirillum, Campylobacter, Thiovulum, Helicobacter and Wolinella. In addition, some members of this lineage

Published online ahead of print on 14 December 2001 as DOI 10.1099/ ijs.0.02195-0.

The GenBank/EMBL accession number for the $16 \mathrm{~S}$ rDNA sequence of strain AM1116 is AJ309655. are found to be the dominant ectosymbionts of some hydrothermal vent metazoans. The single phylotype recovered from nucleic acids extracted from epibionts of the Atlantic hydrothermal shrimp Rimicaris exoculata was found to belong to the $\varepsilon$-Proteobacteria and also to be the major component of the free-living substrate community at this site (Polz \& Cavanaugh, 1995). The filamentous ectosymbionts of the annelid polychaete Alvinella pompejana (Haddad et al., 1995; Cary et al., 1997), thriving at East Pacific Rise hydrothermal vents, were also found to belong to this lineage. These ectosymbionts were thought to contribute to protection against sulphide toxicity and/or to the nutrition of their host (Alayse-Danet et al., 1987; Desbruyères et al., 1998). Many attempts to culture them have been made in our laboratory (unpublished results) and in other laboratories (Prieur 
\& Jeanthon, 1987; Prieur et al., 1990; Jeanthon \& Prieur, 1990; Campbell et al., 2001), under a wide range of temperatures in combination with different electron donors, electron acceptors and carbon sources, but, to date, none of them has been successful.

The second lineage contains environmental clone sequences from different hydrothermal communities that have been investigated by molecular phylogenetic approaches. Members of the $\varepsilon$-Proteobacteria have been identified from both deep-sea Atlantic and Pacific vents (Polz \& Cavanaugh, 1995; Moyer et al., 1995; Reysenbach et al., 2000; Longnecker \& Reysenbach, 2001; Campbell et al., 2001). In all the deep-sea hydrothermal vent microbial communities studied, $\varepsilon^{-}$ Proteobacteria phylotypes were found to be dominant, accounting for $40-98 \%$ of the bacterial clone sequences (Moyer et al., 1995; Reysenbach et al., 2000; Longnecker \& Reysenbach, 2001). Analyses of their numerical importance, using fluorescent in situ hybridization or $16 \mathrm{~S}$ rRNA-based quantitative oligonucleotide hybridization techniques, have demonstrated that these $\varepsilon$-proteobacteria were abundant, and even dominant, in the communities studied (Polz \& Cavanaugh, 1995; Longnecker \& Reysenbach, 2001). Their metabolism, their potential impact on the biogeochemistry and their place in the food chain of this ecosystem have remained undefined because, until recently (Campbell et al., 2001), all attempts to culture them have failed.

In 1999, hydrothermal samples were collected from a deep-sea vent field located on the East Pacific Rise $\left(13^{\circ} \mathrm{N}\right)$. In this paper, we describe the isolation and the characterization of a thermophilic member of the $\varepsilon$-Proteobacteria belonging to the second lineage.

\section{METHODS}

Collection of samples. In 1999, a deep-sea vent field located on the East Pacific Rise [Elsa (HOT3), $103^{\circ} 56^{\prime} \mathrm{W}, 12^{\circ} 48^{\prime} \mathrm{N}$ ] was explored during the AMISTAD (Advanced Microbiological Studies of Thermophiles: Adaptations and Diversity) oceanographic cruise. Entire young tube samples of the hydrothermal vent polychaete Alvinella pompejana, which inhabits the surface of active sulphide structures ("chimneys', 'smokers'), attached to small fragments of chimney rock, were collected by the man-operated Nautile submersible. The temperature ranged from 10 to $100{ }^{\circ} \mathrm{C}$ and the pressure was $26 \mathrm{MPa}$ at the hydrothermal sampling site and the temperature recorded in the Alvinella pompejana colony was approximately $45-49^{\circ} \mathrm{C}$ with a $\mathrm{pH}$ of $5 \cdot 8$. After collection, the samples were transferred immediately into an anaerobic chamber and then, after removal of the tube's inner contents, into $50 \mathrm{ml}$ serum vials filled with a sterile solution of $3 \%(\mathrm{v} / \mathrm{v})$ sea salts (Sigma). They were stored at $4{ }^{\circ} \mathrm{C}$ until enrichment in the laboratory.

Culture medium and conditions. The isolate was enriched and grown on KA22 medium containing $\left(1^{-1}\right): 30$ g sea salts (Sigma), $2.54 \mathrm{~g} \mathrm{Mg}\left(\mathrm{NO}_{3}\right)_{2} \cdot 6 \mathrm{H}_{2} \mathrm{O}$ (Merck), $1.95 \mathrm{~g}$ MES buffer (Sigma), $12 \mathrm{~g}$ elemental sulphur (Prolabo), 0.3 g $\mathrm{KH}_{2} \mathrm{PO}_{4}$ (Sigma), $0.5 \mathrm{ml}$ vitamin mixture (Balch et al., 1979), $10 \mathrm{ml}$ trace element solution (Balch et al., 1979) and
$1 \mathrm{mg}$ resazurin (Sigma). The $\mathrm{pH}$ of the medium was adjusted to 6.0 at room temperature before autoclaving and the medium was reduced with $0.5 \mathrm{~g}$ sodium sulphide $1^{-1}$ before inoculation. A mixture of $\mathrm{H}_{2} / \mathrm{CO}_{2}(80: 20 ; 200 \mathrm{kPa})$ was used as the gas phase. Unless indicate otherwise, cultures were incubated at $60{ }^{\circ} \mathrm{C}$.

Enrichment and purification procedures. Cultures were enriched anaerobically in KA22 medium inoculated with solid fragments of young Alvinella pompejana tubes, in $50 \mathrm{ml}$ serum vials (Balch \& Wolfe, 1976). They were incubated at $60{ }^{\circ} \mathrm{C}$ for $20 \mathrm{~h}$ under an atmosphere of $\mathrm{H}_{2} / \mathrm{CO}_{2}(80: 20$; $200 \mathrm{kPa}$ ). Cells were visualized by microscope observation. After enrichment, positive cultures were subcultured and then purified by use of the dilution-to-extinction technique (Baross, 1995). Purity of the isolate was confirmed by microscope observations and by cloning and sequencing of ten independent $16 \mathrm{~S}$ rDNA clones.

Observation of the culture and quantification. Cells were observed under a light microscope (model BH2; Olympus) equipped with a phase-contrast oil immersion objective ( $\times 100$ magnification). Cells were quantified by direct cell counting using a Thoma chamber (depth 0.02 mm). Alternatively, cells were fixed with $1 \%(\mathrm{v} / \mathrm{v})$ glutaraldehyde for $45 \mathrm{~min}$ at room temperature and stored at $-20{ }^{\circ} \mathrm{C}$ before being counted in a Thoma chamber.

Morphology. The cells were Gram stained by use of the Bacto 3-step Gram stain Set-S (Difco). SpotTest flagella stain (Difco) was used for flagella detection. For scanning electron microscopy, cells were fixed with $10 \%$ formaldehyde $(\mathrm{v} / \mathrm{v})$ for $1 \mathrm{~h}$ and then harvested by centrifugation for $20 \mathrm{~min}$ at $1000 \mathrm{~g}$. The pellets were resuspended in $23 \mathrm{~g}$ $\mathrm{NaCl} 1^{-1}$, displayed on filters $(0 \cdot 22 \mu \mathrm{m}$ pore size, Nucleopore) and dried overnight at room temperature. Samples were then coated with gold (SCD040; Balzers) and examined with a scanning electron microscope (XL 30 LaB6; Philips).

Determination of growth parameters. To determine the optimum temperature, $\mathrm{pH}$ and $\mathrm{NaCl}$ for growth, cells were grown in Hungate tubes (27 ml; Bellco) containing $5 \mathrm{ml}$ KA22 medium and $\mathrm{H}_{2} / \mathrm{CO}_{2}$ at a pressure of $200 \mathrm{kPa}$ in the headspace. Experiments were performed in thermostatic aluminium heating blocks (Bioblock) monitored with temperature probes placed in control tubes. To determine the effect of $\mathrm{pH}$ on growth, KA22 medium was modified with the following buffers (each at $10 \mathrm{mM}$; Sigma): for $\mathrm{pH} 3$ and 4, no buffer; for $\mathrm{pH} 5,5.5$ and 6 , MES; for $\mathrm{pH} 6.5$ and 7 , PIPES; for $\mathrm{pH} 7.5$ and 8, HEPES; for $\mathrm{pH} 8.5$ and 9, AMPSO. Sodium sulphide was added in the anaerobic chamber and, if necessary, the $\mathrm{pH}$ was adjusted with $0 \cdot 1 \mathrm{M}$ $\mathrm{HCl}$ or $0.1 \mathrm{M} \mathrm{NaOH}$. To determine the effect of salinity on growth, KA22 medium was prepared without sea salts and with different concentrations of $\mathrm{NaCl}$. For this experiment, the following salts were added to the medium $\left(1^{-1}\right): 1 \cdot 0 \mathrm{~g}$ $\mathrm{NH}_{4} \mathrm{Cl}, 0 \cdot 2 \mathrm{~g} \mathrm{MgCl}_{2} \cdot 6 \mathrm{H}_{2} \mathrm{O}, 0 \cdot 1 \mathrm{~g} \mathrm{CaCl}_{2} .2 \mathrm{H}_{2} \mathrm{O}, 0 \cdot 1 \mathrm{~g} \mathrm{KCl}$ and $0 \cdot 3 \mathrm{~g} \mathrm{~K}_{2} \mathrm{HPO}_{4}$. Cells were then incubated at the optimum temperature and $\mathrm{pH}$ for growth. The effects of temperature, $\mathrm{pH}$ and salinity were determined by measuring growth rates calculated by use of linear regression analyses from four to seven points along the logarithmic portions of the growth curves. All growth experiments were carried out in triplicate.

Determination of growth requirements. The ability of isolate $\mathrm{AM} 1116^{\mathrm{T}}$ to use various electron donors was investigated. Formate $(20 \mathrm{mM})$, acetate $(20 \mathrm{mM}), 0 \cdot 5 \%$ methanol $(\mathrm{v} / \mathrm{v})$ or $2 \mathrm{~g}$ yeast extract $1^{-1}$ were added to the KA22 medium with a $\mathrm{N}_{2} / \mathrm{CO}_{2}$ gas phase $(80: 20,200 \mathrm{kPa})$. 
The ability of the novel isolate to grow in the presence of different electron acceptors was tested on KA22 medium prepared without sulphur in which $\mathrm{Mg}\left(\mathrm{NO}_{3}\right)_{2}$ was replaced with $1 \mathrm{~g} \mathrm{NH}_{4} \mathrm{Cl} \mathrm{l}^{-1}$. Elemental sulphur and L-cystine were tested at $12 \mathrm{~g}^{-1}$, polysulphides at $10 \mathrm{mM}$ (Blumentals et al., 1990) and thiosulphate, sulphate, nitrate and nitrite at $20 \mathrm{mM}$. The headspace gas was $\mathrm{H}_{2} / \mathrm{CO}_{2}(80: 20 ; 200 \mathrm{kPa})$. Microaerobic media, containing a gas phase of $\mathrm{H}_{2} / \mathrm{CO}_{2}$ $(200 \mathrm{kPa})$ and low concentrations of oxygen [from approximately 0.05 to $0.5 \%(\mathrm{v} / \mathrm{v}) \mathrm{O}_{2}$ ], were prepared without resazurin and sodium sulphide.

The ability of strain AM1116 ${ }^{\mathrm{T}}$ to utilize different carbon sources was investigated by adding the following compounds to the KA22 medium: formate $(20 \mathrm{mM})$, acetate $(20 \mathrm{mM})$, lactate $(0.5 \% \mathrm{v} / \mathrm{v})$, methanol $(0.5 \% \mathrm{v} / \mathrm{v})$, yeast extract $\left(2 \mathrm{~g} \mathrm{l}^{-1}\right)$, tryptone $\left(2 \mathrm{~g} \mathrm{l}^{-1}\right)$, brain/heart infusion $\left(2 \mathrm{~g} \mathrm{l}^{-1}\right)$, peptone $\left(2 \mathrm{~g}^{-1}\right)$, gelatin $\left(2 \mathrm{~g} \mathrm{l}^{-1}\right)$, glycogen $\left(2 \mathrm{~g} \mathrm{l}^{-1}\right)$, $\mathrm{D}-(+)$ glucose $\left(2 \mathrm{~g} \mathrm{l}^{-1}\right)$, D- $(-)$-fructose $\left(2 \mathrm{~g} \mathrm{l}^{-1}\right)$, D- $(+)$-galactose $\left(2 \mathrm{~g} \mathrm{l}^{-1}\right)$, maltose $\left(2 \mathrm{~g} \mathrm{l}^{-1}\right)$, starch $\left(2 \mathrm{~g} \mathrm{l}^{-1}\right)$, chitin $\left(2 \mathrm{~g} \mathrm{l}^{-1}\right)$, dextran $\left(2 \mathrm{~g} \mathrm{l}^{-1}\right)$, xylan $\left(2 \mathrm{~g}^{-1}\right)$, cellulose $\left(2 \mathrm{~g} \mathrm{l}^{-1}\right)$, $\mathrm{D}-(+)$ cellobiose $\left(2 \mathrm{~g} \mathrm{l}^{-1}\right)$ and a mixture of 20 amino acids (each at $\left.0 \cdot 1 \mathrm{~g} \mathrm{l}^{-1}\right)$. This experiment was performed under a $\mathrm{H}_{2}(100 \%$, $200 \mathrm{kPa}$ ) gas phase. All these tests were performed in serum vials and positive cultures were transferred to confirm growth. Growth was determined by direct cell counts in a Thoma chamber (depth $0.02 \mathrm{~mm}$ ) with a phase-contrast microscope.

Determination of $\mathrm{H}_{2} \mathrm{~S}$. $\mathrm{H}_{2} \mathrm{~S}$ formation was detected by the addition of $500 \mu \mathrm{l} 5 \mathrm{mM} \mathrm{CuSO}_{4} / 50 \mathrm{mM} \mathrm{HCl}$ to $0.2 \mathrm{ml}$ of the culture. A brown precipitate demonstrated the presence of $\mathrm{H}_{2} \mathrm{~S}$.

Determination of ammonia. $\mathrm{NH}_{3} / \mathrm{NH}_{4}^{+}$formation was analysed as described by Koroleff (1969), with the modifications reported by Aminot \& Chaussepied (1983). This method is based on the formation of indophenol blue, which absorbs at $630 \mathrm{~nm}$ in the presence of $\mathrm{NH}_{3}$ or $\mathrm{NH}_{4}^{+}$. For this experiment, cells were grown on KA22 medium prepared without sulphur and $\mathrm{NO}_{3}^{-}$was therefore the sole electron acceptor. This test was carried out in duplicate and repeated twice.

Susceptibility to antibiotics. Sensitivity to antibiotics was estimated by using $25,50,75$ and $100 \mu \mathrm{g} \mathrm{ml}^{-1}$ solutions of the following antibiotics: chloramphenicol, kanamycin, penicillin $\mathrm{G}$, rifampicin, streptomycin and vancomycin. Antibiotic solutions were added to KA22 medium just before inoculation. When the antibiotic was diluted in ethanol (chloramphenicol) or DMSO (rifampicin), the same volume of solvent was added to control cultures.

DNA extraction and purification. Genomic DNA was extracted as described by Wery et al. (2001). The concentration and purity of the genomic DNA obtained were estimated by use of a GenQuant II spectrophotometer (Pharmacia) at 260, 280 and $320 \mathrm{~nm}$. The quality of the extraction was checked on a $0.8 \%(\mathrm{w} / \mathrm{v})$ agarose gel containing $0.5 \mu \mathrm{g}$ ethidium bromide $\mathrm{ml}^{-1}$.

DNA base composition. The DNA was purified by caesium chloride gradient centrifugation (Sambrook et al., 1989) and its purity was checked spectrophotometrically. The $\mathrm{G}+\mathrm{C}$ content of the genomic DNA was determined from the melting point according to Marmur \& Doty (1962), under the conditions reported by Raguénès et al. (1997). A calibration curve was constructed by use of ultrapure DNA from Escherichia coli strain B $(50 \mathrm{~mol} \% \mathrm{G}+\mathrm{C})$, Clostridium perfringens $(26.5 \mathrm{~mol} \% \mathrm{G}+\mathrm{C})$ and Micrococcus luteus $(72 \mathrm{~mol} \% \mathrm{G}+\mathrm{C}$ ) as standards (Sigma).
Amplification of the 16S rDNA. The 16S rDNA was selectively amplified from purified genomic DNA by PCR with oligonucleotide primers designed to anneal to conserved positions in the $3^{\prime}$ and $5^{\prime}$ regions of the $16 \mathrm{~S}$ rRNA genes. The forward primer was SAdir (5'-AGAGTTTGATCATGGCTCAGA-3'), corresponding to positions 8-28 in the E. coli $16 \mathrm{~S}$ rRNA, and the reverse primer was S17rev (5'-GTTACCTTGTTACGACTT-3'), corresponding to positions 14931509. The initial denaturation step consisted of heating the reaction mixture to $94{ }^{\circ} \mathrm{C}$ for $3 \mathrm{~min}$. This was followed by 30 cycles of denaturation at $94{ }^{\circ} \mathrm{C}$ for $1 \mathrm{~min}$, annealing at $49^{\circ} \mathrm{C}$ for $90 \mathrm{~s}$ and extension at $72^{\circ} \mathrm{C}$ for $2 \mathrm{~min}$. A final extension step was carried out at $72{ }^{\circ} \mathrm{C}$ for $6 \mathrm{~min}$. The PCR products were analysed on $0.8 \%(\mathrm{w} / \mathrm{v})$ agarose TAE gels $(0.04 \mathrm{M}$ Tris/acetate, 0.001 M EDTA) containing $0.8 \mu \mathrm{g}$ ethidium bromide $\mathrm{ml}^{-1}$ and recorded with a Fluor-S multiImager (Bio-Rad).

16S rDNA sequence analysis. The PCR product was sequenced bidirectionally with the primers described by Raguénès et al. (1996) by Genome Express SA (Grenoble, France) with an automatic DNA analysis system (Applied Biosystems). Some 1414 positions of the 16S rDNA were determined. The $16 \mathrm{~S}$ rDNA sequence of strain AM1116 was compared to the sequences of representative proteobacteria and clones from hydrothermal vents. The CLUSTAL $\mathrm{w}$ method with weighted residues was used to align the sequences and to calculate similarity levels (Thompson et al., 1994). Alignment was refined manually by use of the multiple sequence alignment editor SEAVIEW and phylogenetic reconstruction was achieved by use of PHYLO_WIN (Galtier et $a l ., 1996)$ with the following settings: Jukes-Cantor distance matrix and successively the neighbour-joining (Saitou \& Nei, 1987), maximum-parsimony (Lake, 1987) and maximum-likelihood (Felsenstein, 1981) methods. Some 1104 nucleotides were included in the phylogenetic analysis. Bootstrap values were determined according to Felsenstein (1985). E. coli K-12 (J01695), Vibrio diabolicus CNCM I$1629^{\mathrm{T}}$ (X99762) and the sequence of the uncultured symbiont of Riftia pachyptila (M99451) were used as outgroups.

\section{RESULTS AND DISCUSSION}

\section{Enrichment and isolation}

Enrichment cultures were performed on KA22 medium with entire young Alvinella pompejana tubes (cleaned of their inner contents) attached to small fragments of chimney rock. After $20 \mathrm{~h}$ incubation, growth was observed at $60^{\circ} \mathrm{C}$ under a $\mathrm{H}_{2} / \mathrm{CO}_{2}(80: 20$; $200 \mathrm{kPa})$ gas phase. The enriched culture consisted of dense populations of short, rod-shaped, motile cells. It was subcultured successfully. One isolate was purified with five serial dilutions to extinction and is referred to as strain AM1116 ${ }^{\mathrm{T}}$ (= DSM 14510 ${ }^{\mathrm{T}}=\mathrm{CIP} 107140^{\mathrm{T}}$ ). The purity of the isolate was confirmed by microscope observations and by cloning and sequencing of ten independent 16S rDNA clones.

\section{Morphological and physiological characteristics}

Scanning electron microscopy and phase-contrast microscopy indicated that cells of isolate AM1116 ${ }^{\mathrm{T}}$ were motile rods, about $1 \cdot 0-1.5 \mu \mathrm{m}$ long and $0.5 \mu \mathrm{m}$ wide. The cells were Gram-negative and appeared to divide 

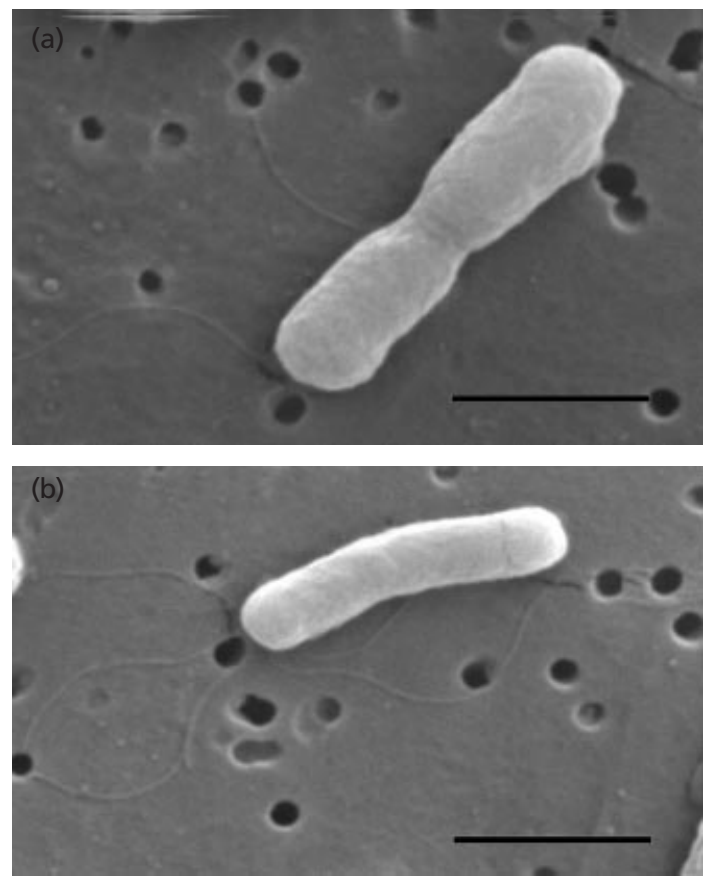

Fig. 1. Scanning electron micrographs of strain $A M 1116^{\top}$ in the mid-exponential phase of growth, showing division by constriction (a) and polar flagella (b). Bars, $1 \mu \mathrm{m}$.

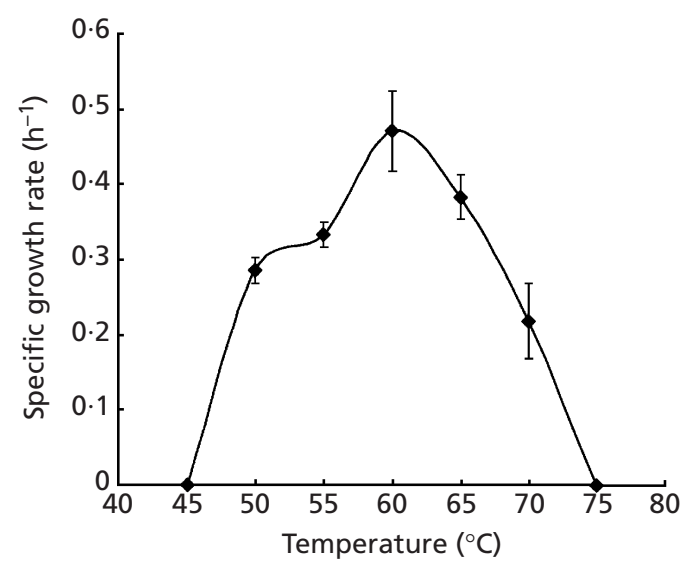

Fig. 2. Effect of temperature on the specific growth rate of strain $A M 1116^{\top}$. The cells were grown in $\mathrm{KA} 22$ medium $(\mathrm{pH} 6.0$, $25 \mathrm{~g} \mathrm{NaCl} \mathrm{I}^{-1}$ ). Growth rates were calculated by performing linear regression analysis along the logarithmic part of the growth curves.

by constriction (Fig. 1a). As observed during scanning electron microscope analyses (Fig. 1b) and confirmed by the SpotTest flagella stain kit (Difco) used for flagella detection, the flagella were polar. Strain AM $1116^{\mathrm{T}}$ grew at temperatures between 50 and $70^{\circ} \mathrm{C}$ with optimum growth at around $60^{\circ} \mathrm{C}$; no growth was observed at 45 or $75^{\circ} \mathrm{C}$ (Fig. 2). Strain AM1116 required $\mathrm{NaCl}$ for growth; growth was observed at $\mathrm{NaCl}$ concentrations of between 10 and $40 \mathrm{~g} \mathrm{l}^{-1}$. The optimum $\mathrm{NaCl}$ concentration was between 20 and

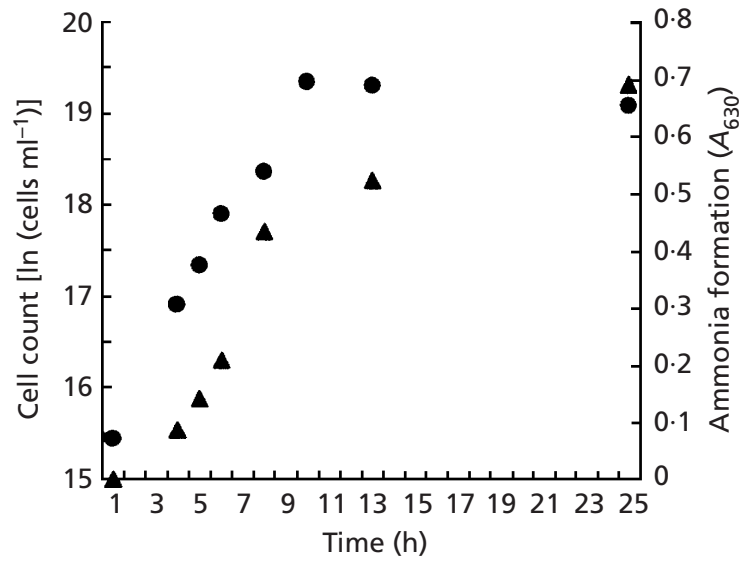

Fig. 3. Ammonia formation during the growth of isolate AM $1116^{\top}$. The growth curve $(\boldsymbol{O})$ and ammonia formation ( $\boldsymbol{\Delta}$ ) (determined by absorbance at $630 \mathrm{~nm}$ of indophenol blue, demonstrating the formation of $\mathrm{NH}_{3} / \mathrm{NH}_{4}^{+}$) are shown.

$25 \mathrm{~g} \mathrm{l}^{-1}$. Growth did not occur at 5 or $45 \mathrm{~g} \mathrm{NaCl}^{-1}$. Growth occurred at between $\mathrm{pH} 5.0$ and 7.5 and the optimum $\mathrm{pH}$ was around $5 \cdot 5-6 \cdot 0$, which corresponded with the $\mathrm{pH}$ recorded in the Alvinella pompejana colony during sampling.

\section{Metabolic properties}

Strain AM1116 ${ }^{\mathrm{T}}$ was an anaerobic, obligately hydrogen-oxidizing bacterium, unable to grow under microaerophilic conditions. It was unable to grow organotrophically on the complex substrates or small organic molecules tested. Growth of the novel isolate was optimal in the presence of elemental sulphur or nitrate as the terminal electron acceptor (doubling times were equal). $\mathrm{H}_{2} \mathrm{~S}$ was produced as a result of sulphur reduction. When nitrate was the terminal electron acceptor, isolate AM1116 ${ }^{\mathrm{T}}$ produced high levels of ammonia or ammonium, which accumulated in the culture medium (Fig. 3). These data suggest that the newly isolated strain is an obligately chemolithotrophic bacterium that produces energy by reducing elemental sulphur or nitrate and by using molecular hydrogen as an electron donor. Of the other electron acceptors tested with $\mathrm{H}_{2}$ as an electron donor and $\mathrm{CO}_{2}$ as a carbon source, strain AM1116 ${ }^{\mathrm{T}}$ was found to reduce cystine slightly (production of $\mathrm{H}_{2} \mathrm{~S}$ ), but not sulphate, thiosulphate or polysulphides. Very strong autotrophic growth occurred with $\mathrm{CO}_{2}$ and weak heterotrophic growth occurred on yeast extract, tryptone, brain/heart infusion, peptone and gelatin. Limited growth observed on complex proteinaceous substrates probably resulted from decarboxylation of amino acids. The other carbon sources tested did not support growth. In optimum growth conditions (with $\mathrm{CO}_{2}$ as a carbon source, $\mathrm{H}_{2}$ as an electron donor, sulphur or nitrate as a terminal electron acceptor and at optimum temperature, $\mathrm{pH}$ and salinity), the final concentration was approximately $2 \cdot 5 \times 10^{8}$ cells $\mathrm{ml}^{-1}$ in vials. 


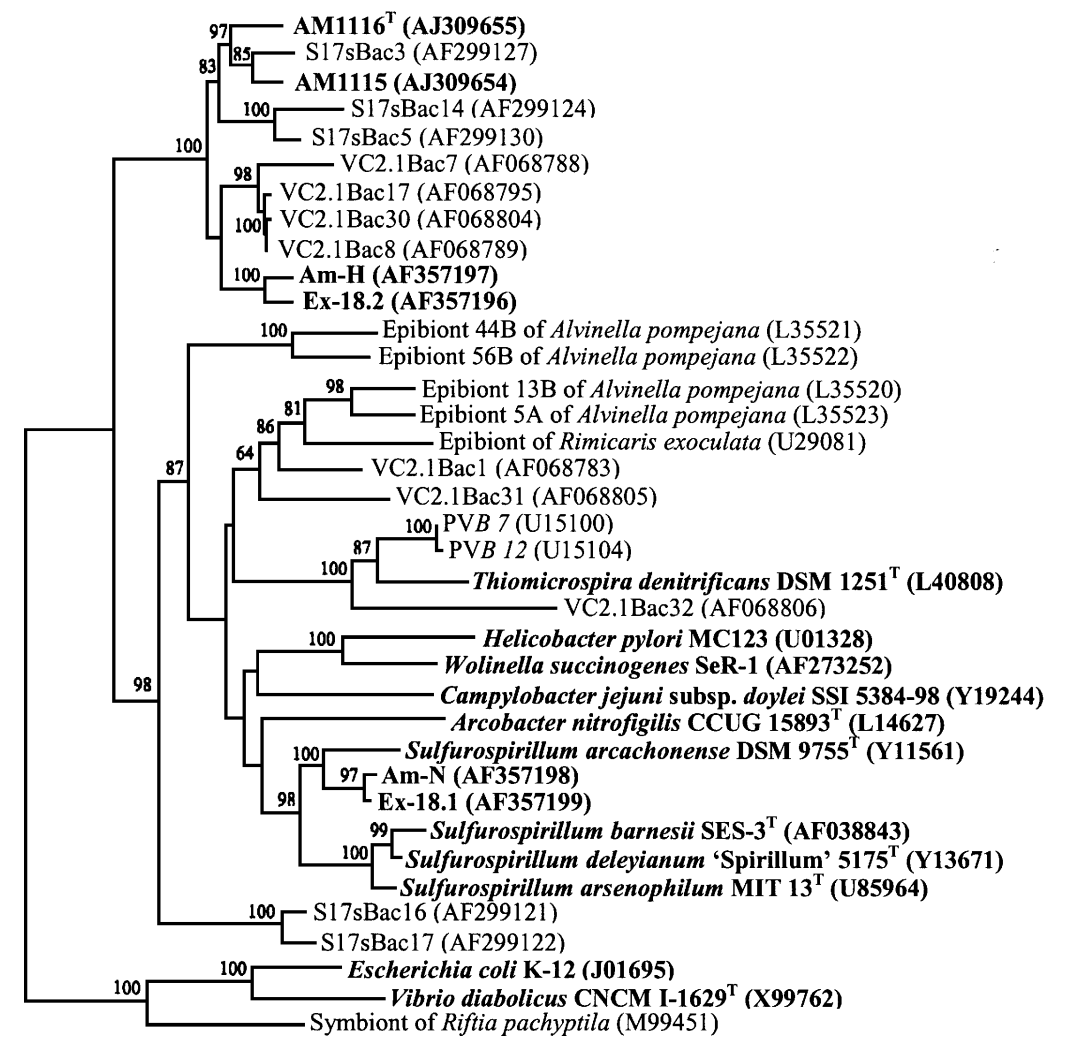

$0 \cdot 072$
Fig. 4. Phylogenetic position of strain $A M 1116^{\top}$ within the $\varepsilon$-Proteobacteria. The alignment was performed with 16S rDNA sequences of representative species of the $\varepsilon^{-}$ Proteobacteria (in bold) and uncultured $\varepsilon$ proteobacteria from Atlantic and Pacific hydrothermal vents. Three species from the $\gamma$-Proteobacteria were chosen as outgroups. Accession numbers and strains are noted in parentheses. The topology shown corresponds to an unrooted tree obtained by a neighbour-joining algorithm (Jukes \& Cantor corrections) established using PHYLO_WIN. A total of 1104 nucleotides were included in the phylogenetic analysis. Bootstrap values are displayed on the branches. Bar, $7.2 \mathrm{nt}$ substitutions per $100 \mathrm{nt}$. The positioning of the novel isolate was confirmed by maximum-parsimony and maximum-likelihood methods.

\section{Susceptibility to antibiotics}

Growth of isolate AM1116 ${ }^{\mathrm{T}}$ was inhibited by $25 \mu \mathrm{g}$ streptomycin, vancomycin, chloramphenicol, rifampicin and penicillin $\mathrm{G} \mathrm{ml}^{-1}$. The strain was resistant to $100 \mu \mathrm{g}$ kanamycin $\mathrm{ml}^{-1}$.

\section{DNA base composition}

The $\mathrm{G}+\mathrm{C}$ content of the genomic DNA of strain AM $1116^{\mathrm{T}}$ was $29 \pm 1 \mathrm{~mol} \%$.

\section{Phylogenetic analysis and taxonomic position of the novel isolate}

The almost-complete sequence (1414 bp) of the $16 \mathrm{~S}$ rDNA of strain AM1116 ${ }^{\mathrm{T}}$ was determined. Phylogenetic analyses of the $16 \mathrm{~S}$ rRNA gene located the strain within the $\varepsilon$-Proteobacteria, in the bacterial domain. The phylogenetic position of the organism was determined by comparing the $16 \mathrm{~S}$ rDNA sequence of strain AM $1116^{\mathrm{T}}$ to those of 14 representative species of the $\varepsilon$-Proteobacteria and $1916 \mathrm{~S}$ rDNA sequences of uncultured members of the $\varepsilon$-Proteobacteria from Atlantic and Pacific hydrothermal vents. The three algorithms used (neighbour-joining, maximum-parsimony and maximum-likelihood) showed that the sequence of $\mathrm{AM} 1116^{\mathrm{T}}$ belonged to a lineage clearly separated from the lineage including the majority of the $\varepsilon$-Proteobacteria described (Fig. 4). This novel lineage has been discovered recently by molecular methods (Polz \& Cavanaugh, 1995; Moyer et al., 1995; Reysenbach et al., 2000; Longnecker \& Reysenbach, 2001). It encompasses only bacteria from deepsea Atlantic and Pacific vents.

The novel isolate was very closely related to several $16 \mathrm{~S}$ rDNA sequences from deep-sea Atlantic vents (VC2.1Bac7, VC2.1Bac17, VC2.1Bac30, VC2.1Bac8 and several other sequences not marked on the phylogenetic tree; Reysenbach et al., 2000) and southeastern Pacific vents (S17sBac3, S17sBac14, S17sBac5 and several other sequences not marked on the phylogenetic tree; Longnecker \& Reysenbach, 2001). They shared $92-95 \%$ 16S rDNA sequence similarity. Moreover, the strain was phylogenetically affiliated to two members of the $\varepsilon$-Proteobacteria found recently in enrichment cultures from the hydrothermal vent polychaete Alvinella pompejana from the East Pacific Rise $13^{\circ} \mathrm{N}$ (strain Am-H) and from chimney samples from the Guaymas basin (strain Ex-18.2) (Campbell et al., 2001). The level of $16 \mathrm{~S}$ rDNA sequence similarity between strain AM1116 and these strains was $92-$ $93 \%$. Some of the metabolic properties of the novel isolate were similar to those of strains $\mathrm{Am}-\mathrm{H}$ and $\mathrm{Ex}-$ 18.2, which have been partially characterized and which are sulphur-reducing bacteria. Strain Am-H has been found to grow chemolithoautotrophically with $\mathrm{H}_{2}$ as the electron donor and $\mathrm{CO}_{2}$ as the carbon source, as is the case for strain AM1116 ${ }^{\mathrm{T}}$. However, although 
strain AM1116 ${ }^{\mathrm{T}}$ shared some characteristics with these two cultivable phylogenetic relatives, it also exhibited significant metabolic and physiological differences, notably its temperature range for growth. Strains Am$\mathrm{H}$ and Ex-18.2 are moderate thermophiles (the optimum growth temperature of strain $\mathrm{Am}-\mathrm{H}$ was $45^{\circ} \mathrm{C}$ and the optimum growth temperature of strain Ex18.2 has not been determined, but the strain was isolated at $45^{\circ} \mathrm{C}$ ). Moreover, these two isolates differed from strain AM $1116^{\mathrm{T}}$ in their ability to grow on formate as the energy and carbon source. In addition, strain Am-H has been found to grow chemoorganoheterotrophically on pyruvate as the electron donor and carbon source. If they belong to the same family as AM1116 ${ }^{\mathrm{T}}$, strains Am-H and Ex-18.2 probably correspond to another genus.

Strain AM1116 ${ }^{\mathrm{T}}$ was closely related to strain AM1115 (95\% 16S rDNA similarity), which was isolated in our laboratory (unpublished data) from the same sample as $\mathrm{AM} 1116^{\mathrm{T}}$ and under the same conditions except that the enrichment temperature was $45^{\circ} \mathrm{C}$. Similar to strain $\mathrm{AM} 1116^{\mathrm{T}}$, this strain is a chemolithoautotrophic bacterium from the microenvironment of Alvinella pompejana that produces energy by using molecular hydrogen as an electron donor and by reducing elemental sulphur (unpublished data).

Although strain AM1116 ${ }^{\mathrm{T}}$ was isolated from a sample taken from the environment of Alvinella pompejana, it belongs to a phylotype that is very distantly related to the filamentous epibiotic $\varepsilon$-proteobacteria of this metazoan (Cary et al., 1997) (mean similarity of 85-86\%). Despite the fact that our isolate was found to be associated with the tubes of Alvinella pompejana, we hypothesize that it is not dependent on them.

On the basis of the overall 16S rRNA dissimilarity value of $17 \%$ between strain $\mathrm{AM} 1116^{\mathrm{T}}$ and the closest fully described relatives (members of the genus Sulfurospirillum) and the fact that strain AM1116 ${ }^{\mathrm{T}}$ and its relatives are distributed widely at deep-sea hydrothermal vents, we propose that strain AM1116 ${ }^{\mathrm{T}}$ should be assigned as the type strain of the type species of a novel genus within the $\varepsilon$-Proteobacteria. Because of its hydrothermal vent origin and its ability to grow lithotrophically on $\mathrm{H}_{2}$, we have named the novel species Caminibacter hydrogeniphilus gen. nov., sp. nov. A novel family will have to be established in the future to encompass this genus and related genera yet to be described.

\section{Ecological significance}

As indicated by their dominance in the molecular surveys that have studied hydrothermal vent communities (Polz \& Cavanuagh, 1995; Moyer et al., 1995; Reysenbach et al., 2000; Longnecker \& Reysenbach, 2001), members of the $\varepsilon$-Proteobacteria certainly have a significant role in the ecology of hydrothermal vents. Their widespread distribution and autotrophic abilities suggest that strain $\mathrm{AM} 1116^{\mathrm{T}}$ and its relatives are probably a major source of primary productivity in hydrothermal vents. Their ability to use $\mathrm{H}_{2}$ as an electron donor and $\mathrm{S}^{0}$ as an electron acceptor may reflect the physiological remains of ancient metabolic pathways that first evolved in primitive organisms because of the ready availability of these inorganic compounds on the primitive Earth. Their ability to reduce elemental sulphur and nitrates in some cases enables them to contribute specifically to the sulphur and nitrogen cycles and more generally to biogeochemical cycling in deep-sea hydrothermal vents. Considering the wide geochemical gradients (nutrients, temperatures, oxygen etc.) present at deep-sea hydrothermal vents, the metabolic and physiological abilities of the $\varepsilon$-proteobacteria from these extreme environments are probably more diverse than has so far been described. Fully appreciating the diversity among the members of the $\varepsilon$-Proteobacteria and more widely among the entire microbial population in deepsea environments is still a substantial challenge.

\section{Description of Caminibacter gen. nov.}

Caminibacter (Ca'mi.ni.bac.ter. L. gen. n. camini of a chimney; N.L. n. bacter masc. equivalent of Gr. neut. n. bakterion rod, staff; N.L. n. Caminibacter rod from a hydrothermal chimney, relating to the origin of the type species).

Cells are rod-shaped, motile and stain Gram-negative. They are thermophiles, adapted to the salinity of the ocean. Anaerobic, hydrogen-oxidizing, sulphur-reducing and denitrifying. Chemolithoautotrophic to mixotrophic. 16S rDNA sequence comparisons locate the genus within the $\varepsilon$-Proteobacteria in the bacterial domain. This genus is not closely related to any described genera. The type and only species is Caminibacter hydrogeniphilus.

\section{Description of Caminibacter hydrogeniphilus sp. nov.}

Caminibacter hydrogeniphilus (hy.dro.ge.ni.phil'us. N.L. hydrogenum hydrogen; Gr. n. philos friend; N.L. adj. hydrogeniphilus hydrogen-liking, referring to its ability to grow lithotrophically on $\mathrm{H}_{2}$ ).

Cells are rod-shaped $(1.0-1.5 \times 0.5 \mu \mathrm{m})$, motile by polar flagella and stain Gram-negative. Cells divide by constriction. Growth occurs at between 50 and $70{ }^{\circ} \mathrm{C}$ (optimum $60{ }^{\circ} \mathrm{C}$ ), $\mathrm{pH} 5.0$ and $7 \cdot 5$ (optimum 5.5-6.0) and 10 and $40 \mathrm{~g} \mathrm{NaCl}^{-1}$ (optimum 20-25 $\mathrm{g} \mathrm{NaCl}^{-1}$ ). Doubling time under optimum growth conditions is around $1.5 \mathrm{~h}$; maximum cell yield is $2.5 \times 10^{8}$ cells ml ${ }^{-1}$ in vials. Anaerobic. Obligately hydrogen-oxidizing. Chemolithoautotrophic to mixotrophic (heterotrophic growth on yeast extract, tryptone, peptone, brain/ heart infusion and gelatin). Reduces $\mathrm{S}^{0}$ and nitrate and, to a lesser extent, cystine. The DNA G+C content of the type strain is $29 \pm 1 \mathrm{~mol} \%$. The GenBank/EMBL accession number for the 16S rDNA sequence of the type strain is AJ309655.

The type strain, strain AM1116 ${ }^{\mathrm{T}}$ (= DSM $14510^{\mathrm{T}}=$ CIP $107140^{\mathrm{T}}$ ), was isolated from young Alvinella 
pompejana tubes attached to fragments of chimney rock that were collected from the hydrothermal site Elsa (HOT3) in the East Pacific Rise $\left(103^{\circ} 56^{\prime} \mathrm{W}\right.$, $\left.12^{\circ} 48^{\prime} \mathrm{N}\right)$.

\section{ACKNOWLEDGEMENTS}

We thank the chief scientists of the French oceanographical cruise AMISTAD (1999), C. Jeanthon, the captain and crew of the NO L'Atalante and the pilots and support crew of the DSV Nautile. This work was supported by Région Bretagne.

\section{REFERENCES}

Alayse-Danet, A.-M., Desbruyères, D. \& Gaill, F. (1987). The possible nutritional or detoxification role of the epibiotic bacteria of alvinellid polychaetes: review of current data. Symbiosis 4, 51-62.

Aminot, A. \& Chaussepied, M. (1983). Dosage de l'azote ammoniacal. In Manuel des Analyses Chimiques en Milieu Marin, pp. 107-118. BNDO/Documentation, CNEXO, France.

Balch, W. E. \& Wolfe, R. S. (1976). New approach to the cultivation of methanogenic bacteria: 2-mercaptoethanesulfonic acid (HS-CoM)dependent growth of Methanobacterium ruminantium in a pressurized atmosphere. Appl Environ Microbiol 32, 781-791.

Balch, W. E., Fox, G. E., Magrum, L. J., Woese, C. R. \& Wolfe, R. S. (1979). Methanogens: reevaluation of a unique biological group. Microbiol Rev 43, 260-296.

Baross, J. A. (1995). Isolation, growth and maintenance of hyperthermophiles. In Archaea: a Laboratory Manual. Thermophiles, pp. 15-23. Edited by F. T. Robb \& A. R. Place. Cold Spring Harbor, NY: Cold Spring Harbor Laboratory.

Blumentals, I. I., Itoh, M., Olson, G. J. \& Kelly, R. M. (1990). Role of polysulfides in reduction of elemental sulfur by the hyperthermophilic archaebacterium Pyrococcus furiosus. Appl Environ Microbiol 56, $1255-1262$

Campbell, B. J., Jeanthon, C., Kostka, J. E., Luther, G. W., III \& Cary, S. C. (2001). Growth and phylogenetic properties of novel bacteria belonging to the epsilon subdivision of the Proteobacteria enriched from Alvinella pompejana and deep-sea hydrothermal vents. Appl Environ Microbiol 67, 4566-4572.

Cary, S. C., Cottrell, M. T., Stein, J. L., Camacho, F. \& Desbruyères, D. (1997). Molecular identification and localization of filamentous symbiotic bacteria associated with the hydrothermal vent annelid Alvinella pompejana. Appl Environ Microbiol 63, 1124-1130.

Desbruyères, D., Chevaldonné, P., Alayse, A.-M. \& 15 other authors (1998). Biology and ecology of the "Pompeii worm" (Alvinella pompejana Desbruyères and Laubier), a normal dweller of an extreme deep-sea environment: a synthesis of current knowledge and recent developments. Deep-sea Res Part II 45, 383-422.

Felsenstein, J. (1981). Evolutionary trees from DNA sequences: a maximum likelihood approach. $J$ Mol Evol 17, 368-376.

Felsenstein, J. (1985). Confidence limits on phylogenies: an approach using the bootstrap. Evolution 30, 783-791.

Galtier, N., Gouy, M. \& Gautier, C. (1996). SEAVIEW and PHYLO_WIN: two graphic tools for sequence alignment and molecular phylogeny. Comput Appl Biosci 12, 543-548.
Haddad, A., Camacho, F., Durand, P. \& Cary, S. C. (1995). Phylogenetic characterization of the epibiotic bacteria associated with the hydrothermal vent polychaete Alvinella pompejana. Appl Environ Microbiol 61, 1679-1687.

Jeanthon, C. \& Prieur, D. (1990). Susceptibility to heavy metals and characterization of heterotrophic bacteria isolated from two hydrothermal vent polychaetes, Alvinella pompejana and Alvinella caudata. Appl Environ Microbiol 56, 3308-3314.

Koroleff, F. (1969). Direct determination of ammonia in natural waters as indophenol blue. In ICES, C. M. 1969/C: 9 Hydr. Comm. Copenhagen: International Council for the Exploration of the Sea.

Lake, J. A. (1987). A rate-independent technique for analysis of nucleic acid sequences: evolutionary parsimony. Mol Biol Evol 4, 167-191.

Longnecker, K. \& Reysenbach, A. L. (2001). Expansion of the geographic distribution of a novel lineage of $\varepsilon$-Proteobacteria to a hydrothermal vent site on the southern East Pacific Rise. FEMS Microbiol Ecol 35, 287-293.

Marmur, J. \& Doty, P. (1962). Determination of the base composition of desoxyribonucleic acid from its thermal denaturation temperature. J Mol Biol 5, 109-118.

Moyer, C. L., Dobbs, F. C. \& Karl, D. M. (1995). Phylogenetic diversity of the bacterial community from a microbial mat at an active, hydrothermal vent system, Loihi Seamount, Hawaii. Appl Environ Microbiol 61, 1555-1562.

Polz, M. F. \& Cavanaugh, C. M. (1995). Dominance of one bacterial phylotype at a Mid-Atlantic Ridge hydrothermal vent site. Proc Natl Acad Sci U S A 92, 7232-7236.

Prieur, D. \& Jeanthon, C. (1987). Preliminary study of heterotrophic bacteria isolated from deep-sea hydrothermal vent invertebrates: Alvinella pompejana (polychaete) and Bathymodiolus thermophilus (bivalve). Symbiosis 4, 87-98.

Prieur, D., Chamroux, S., Durand, P., Erauso, G., Fera, P., Jeanthon, C., Le Borgne, L., Mével, G. \& Vincent, P. (1990). Metabolic diversity in epibiotic flora associated with the pompeii worms, Alvinella pompejana and Alvinella caudata (Polychaeta: Annelida) from deep-sea hydrothermal vents. Mar Biol 106, 361-367.

Raguénès, G., Pignet, P., Gauthier, G., Peres, A., Christen, R., Rougeaux, H., Barbier, G. \& Guezennec, J. (1996). Description of a new polymer-secreting bacterium from a deep-sea hydrothermal vent, Alteromonas macleodii subsp. fijiensis, and preliminary characterization of the polymer. Appl Environ Microbiol 62, 67-73.

Raguénès, G., Christen, R., Guézennec, J., Pignet, P. \& Barbier, G. (1997). Vibrio diabolicus sp. nov., a new polysaccharide-secreting organism isolated from a deep-sea hydrothermal vent polychaete annelid, Alvinella pompejana. Int J Syst Bacteriol 47, 989-995.

Reysenbach, A. L., Longnecker, K. \& Kirshtein, J. (2000). Novel bacterial and archaeal lineages from an in situ growth chamber deployed at a Mid-Atlantic Ridge hydrothermal vent. Appl Environ Microbiol 66, 3798-3806.

Saitou, M. \& Nei, M. (1987). The neighbor-joining method: a new method for reconstructing phylogenetic trees. Mol Biol Evol 4, 406-425.

Sambrook, J., Fritsch, E. F. \& Maniatis, T. (1989). Molecular Cloning: a Laboratory Manual, 2nd edn. Cold Spring Harbor, NY: Cold Spring Harbor Laboratory.

Thompson, J. D., Higgins, D. G. \& Gibson, T. J. (1994). CLUSTAL W: improving the sensitivity of progressive multiple sequence alignment through sequence weighting, position-specific gap penalties and weight matrix choice. Nucleic Acids Res 22, 4673-4680.

Wery, N., Lesongeur, F., Pignet, P., Derennes, V., CambonBonavita, M.-A., Godfroy, A. \& Barbier, G. (2001). Marinitoga camini gen. nov., sp. nov., a rod-shaped bacterium belonging to the order Thermotogales, isolated from a deep-sea hydrothermal vent. Int $J$ Syst Evol Microbiol 51, 495-504. 